\title{
Factors Influencing the Development of China's Corporate Bond Market and Relevant Suggestions
}

\author{
Hui Sui \\ School of Accounting, Shandong Economic University, Jinan 250014, China \\ E-mail: suihui696@163.com
}

Received: May 24, 2011 Accepted: June 10, 2011 doi:10.5539/ijbm.v6n9p258

\begin{abstract}
China's laggard development in corporate bond market as well as its imbalanced development in capital market has greatly increased the risks in China's financial system. This paper is mainly intended to analyze some factors influencing the development of China's bond market as well as to come up with some suggestions with the purpose to promote relevant development in China.

Keywords: Bond market, Bond issuance, Bond rating, Marketization

In recent years, in contrast to a big leap in its stock market, China's bond market, especially corporate bond market hasn't achieved rapid development along with imbalanced development in the whole capital market. In all aspects including scale, variety as well as the level of market, there is a wide gap between China's corporate bond market and that of developed nations. Due to underdeveloped financing market, a majority of Chinese enterprises have got their external capital from bank loans and the stock market are under great financing pressure as well, which increases the risks in China's whole financial system. Therefore, it is an important decision to greatly develop corporate bond financing as well as to adjust imbalanced capital market in order to accelerate the sound development of China's capital market, to widen corporate financing channel, to lessen risks for China's financial system and to promote economic reforms. Based on an analysis on some factors influencing China's bond market development, this paper puts forward some suggestions in order to offer some constructive suggestions on the improvement of China's corporate bond market.
\end{abstract}

\section{Factors Influencing the Development of China's Bond Market}

Currently, factors influencing China's corporate bond market mainly include:

\subsection{Lack of Innovative Varieties of Corporate Bonds}

It is another important restrictive factor that China has a monotonous variety of and inconstantly issued corporate bonds. There is basically one single pattern for bond pricing, that is, to give a $40 \%$ plus on the basis of the savings interest rate of the same period, which seems fixed lacking in flexibility and innovation. In addition, its 3-5 years' period is too monotonous as well. As a result, such a bond system has no strong attraction for investors. Besides, its unfixed issuance and opaque market keep investors from being informed about relevant issuance information. All these factors lead to investors' fewer choices and greater difficulties in avoiding risks. If corporate bonds are not priced following the principle of profits going with risks, that is, the same bond period leads to the same price regardless of corporate reputation, repaying ability as well as the level of risks, a disorder will arise in signals for pricing corporate bonds. As a result, its low interest rates, with some corporate bonds even offering lower interest rates than national debts of the same period, discourage investors' activity in purchasing corporate bonds to some extent.

\subsection{Excessive Administrative Control over Corporate Bond Issuance}

The institutional element is a major factor lagging corporate bonds behind. In spite of the reforms in national debt and policy-oriented bank bonds in recent years, a newly-issued corporate bond has to go through quite a few departments. Besides, only those key construction projects recognized nationally or locally are permitted to finance for leaks in project funds by issuing corporate bonds. Currently in China, government and financial institutions are still the main body for issuing national debt and financial bonds in which national debt has the largest issuance volume and constantly-expanded issuance scale in contrast to shrinking corporate bonds. Due to excessive administrative interference, some enterprises fail to issue their bonds, hence lessening their enthusiasm and leading to corporate bonds' failure in adapting themselves to market requirements in terms of interest rates and period structure and therefore restricting the development of China's corporate bond market.

\subsection{Lack of Authoritative Credit Rating Institutions}

At corporate bond market, credit rating institutions are able to offer objective and fair criteria for investment 
decisions. The credit rate of corporate bonds signals the credit degree of bonds as well as enterprises' paying capacity, hence influencing financing cost and difficulty in sales. Some institutions in U.S. have obtained world recognition just due to subjective, fair and authoritative images they have established at market. In China, however, regardless of the great number, such institutions have a poor reputation with their vicious competition with unreasonable prices and promising rates in advance. Unreliable rating conclusions fail to reflect actual risks, hence getting no market recognition. Some other institutions, lacking in complete appraisal standards, systems and independent status, are inclined to draw non-objective results propelled by interest. As a result, investors are quite doubtful about these institutions' appraisal results, influencing purchase and development of corporate bonds.

\subsection{Underdeveloped Secondary Corporate Stock Market}

Transactions at secondary corporate stock market are divided into internal market and external market which is further divided into national and local markets. There is no universal market system, no enough institution investors, no trader or market-maker specialized for corporate bond market. All these factors have largely restricted the flow of trading on an organized exchange. In addition, due to the small scale of corporate bond issuance, institutions find it difficult for them to enter this field, leading to inactive trading at this market along with low hand change rate, inconvenience for investors to invest in corporate bond market and unobvious cost advantages enterprises accumulate through the stock market, which directly results in the laggard development of this market.

\subsection{Poor Information Disclosure}

In accordance with relevant laws and regulations issued after the simplification of approval procedures in 2008, enterprises are required to submit bond raising instruction book, financial report, credit rating report, legal opinion and so on during their application for issuing bonds. In U.S., in order to fully guarantee the creditor's interest, floaters are required to disclose historical credit records including paying records of bank loans, historical credit-violation records, degree of loan concentration, credit records of senior executives in addition to relevant financial and business information. Compared with developed countries, China has relatively lower standards for the disclosure of issuance documents. Besides, due to insufficient importance attached to as well as undemanding requirements for constant information disclosure in corporate bonds, the recent two years has witnessed a rapidly expanded issuance scale. It is also a serious problem that poor quality of application documents due to underwriters' loose control caused by the great number of corporate applicants in an integrated period.

\section{Suggestions on the Development of China's Bond Market}

A dynamic stock market is called for in order to achieve constant and sound development of national economy, especially bond market complying with international conventions, reflecting market economy demands and having high security and mobility. Some suggestions are put forward in accordance with current influential elements and problems at China's bond market.

\subsection{Adjusting and Innovating Variety Structure of Corporate Bonds}

The variety structure of corporate bonds should be adjusted and innovated to pluralism. With the rapid development of national economy and increasing per capita disposable income, China's current varieties of corporate bonds are far from satisfying investors' demands. Bonds should be arranged according to the development history and practical situation of China's corporate bond market as well as advanced experience of the world. First, different organizational forms of the bond issuer should be based on when issuing bonds, such as industrial companies, listed companies, public facilities, key construction projects, large-scale basic facilities and so on; second, with China's insufficient risk awareness among investors, bond varieties should be arranged from the perspective of the source of sinking funds or credit basis. Therefore, China's corporate bonds can be set in two categories: first is corporate bond, which refers to that issued by companies with limited liability and stock companies regulated by Company Act covering listed companies or stock companies as well as transferable corporate bonds or exchangeable funds. The most significant characteristic of this bond is that accumulated capital is not necessarily for projects invested by fixed assets since it is based on previous operation result and current credit qualifications. The second type, similar to municipal bonds applied universally in the world, is issued by industrial companies, key construction projects as well as construction projects for large-scale basic facilities in which accumulated capital has to be used for projects invested by fixed assets and its credit basis lies in issuers or investment projects' stable cash flow. Therefore, the variety structure of corporate bonds should be optimized to promote the diverse development of China's corporate bonds.

\subsection{Transforming Authorized Issuance System to Registered Issuance System}

The current bond issuance system must be changed from the authorized system to the registered system in order to largely develop China's corporate bond market. Substantive management is still employed in the authorized system, according to which all bonds in accordance with issuance standards should be approved of by administrative bureaus. Administrative and supervisory departments are supposed to put emphasis on inspecting enterprises' capacity in paying principal and interest to avoid some poor-quality bonds being issued. After 
registration in bond issuance institutions, enterprises can issue their bonds on demand. It is the market itself that makes its judgment on the risk and value of corporate bonds and makes its decision whether to accept this bond, hence achieving market subjects' self-discipline. It is wise to transform to the registered system to eliminate the restrictions on the qualification of issuance subjects, issuance limit, issuance interest and to enable the market to decide whether to issue corporate bonds and the quantity of bonds to issue, hence establishing real market-oriented bond issuance system.

\subsection{Developing Bond Rating System and Enhancing Supervision on Credit Rating Institutions}

Bond rating is intended to publicize the reputation and reliability of bond issuance units among investors. In this way, bonds can be sold in a wider range and investors can be protected from losses caused by insufficient information and misjudgment as well. It will help to reduce or avoid some immoral actions such as agencies offering their approval with financial benefits to establish a national credit rating standard. In mature market economy, credit rating on corporate bonds should be conducted by independent agencies with independent possession, unlimited liability and earning profit by selling their rating results. In addition, a set of widely-recognized credit rating system should be established to cultivate companies similar to Moody Company and Standard and Poor Company in China, hence making more authoritative and reliable results as well as enhancing investors' confidence. Only with high reputation of these institutions among investors and their results widely accepted will China's corporate bond market be profoundly developed.

\subsection{Guiding Corporate Bonds to Be Marketized}

Instead of scale control, issuance of corporate bonds is to be transformed into marketized issuance. As a result, enterprises are able to choose the price and quantity of bonds they issue with the help of marketized agencies. In such a system, the supervision department takes the role of perfecting market regulations. First of all, legal verification should be conducted to enhance supervision on bond agencies. In addition, agencies should be endowed with greater rights and responsibilities to guarantee corporate bond issuance. At the bond transaction market, current resources should be made full use of to open new transaction channels, to establish a national market system, to remove market division, to perfect transaction network. Besides, some joint efforts should be made to cultivate institution investors at the stock market to create conditions for them to take an active role in the bond market and to eventually form a competitive and vigorous bond market system.

\subsection{Perfecting Information Disclosure System}

It is essential for marketized issuance of corporate bonds to perfect information disclosure system. Therefore, definite principles for information disclosure and constant reporting as well as monitoring on information disclosure seem particularly important. Issuer presentation system should be introduced into the bond market, in which through real-time, open and interactive online communication issuers learn about investors' intentions, answer their questions and help them to have an accurate judgment of investment value. In addition, smooth and effective channels for constant information disclosure should be established to regularly publicize bond-issuing enterprises' project progress, assets and liability, source for paying capital as well as some big events which have strong impacts on bond price or principal-interest payment and so on in order to help investors to make corresponding decisions. Besides, in order to solve poor check of underwriters, a marketized major underwriter recommendation system should be introduced to emphasize the major underwriter's responsibility. Meanwhile, cost for violating laws and regulations should be raised to strictly punish unreal, untimely and insufficient information disclosure.

\section{References}

Dong, Dengxin. (2010). Transformation of China's Corporate Financing System in the Past 30 Years. International Finance, (12).

Hua, Zhongwei \& Gu, Xiaoqing. (2010). Constantly Improved Financing Function of Bond Market. Industry of China, (09).

Liu, Lijie. (2001). Research and Innovation of Credit Rating Index System for China's Corporate Bonds. Securities and Futures of China, (09).

Yan, Bo. (2010). Reforms in Credit Rating Institution and the Development of American Bond Market. China Finance, (23). 